Nils Meyer and Georg Pohnert*

\title{
Isolate-specific resistance to the algicidal bacterium Kordia algicida in the diatom Chaetoceros genus
}

https://doi.org/10.1515/bot-2019-0007

Received 23 January, 2019; accepted 5 July, 2019; online first 14 August, 2019

\begin{abstract}
Algicidal bacteria can lyse phytoplankton cells, thereby contributing to algal bloom dynamics in the oceans. The target specificity of these bacteria determines their ecological impact. While species specificity of algicidal bacteria is documented, little is known about intraspecies variability of their activity against phytoplankton. We describe variability in the Chaetoceros genus (Bacillariophyceae) to resist the lytic activity of the algicidal Flavobacterium Kordia algicida. This variability is evident between different Chaetoceros species, but even intraspecific variability of resistance is observed within one phytoplankton sample. This proves an ecological role of the individuality of diatom cells within a bloom.
\end{abstract}

Keywords: algicidal bacteria; diatoms; plankton; resistance; strain specificity.

\section{Introduction}

Phytoplankton is the basis of marine food webs and accounts for approximately 50\% of the global primary production (Behrenfeld et al. 2006). Phytoplankton performance depends on numerous abiotic and biotic factors. Among the biotic factors phytoplankton pathogens play an important role in population control including bacteria, viruses and fungi (Brussaard and Martínez-Martínez 2008, Gachon et al. 2010, Meyer et al. 2017). Interactions with marine bacteria can include anything ranging from symbiotic to algicidal processes (Amin et al. 2012). If bacteria are algicidal they

\footnotetext{
*Corresponding author: Georg Pohnert, Institute for Inorganic and Analytical Chemistry, Bioorganic Analytics, Friedrich Schiller University Jena, Lessingstrasse 8, D-07743 Jena, Germany; and Max Planck Institute for Chemical Ecology, Hans Knöll Str. 8, D-07745 Jena, Germany, e-mail: georg.pohnert@uni-jena.de Nils Meyer: Institute for Inorganic and Analytical Chemistry, Bioorganic Analytics, Friedrich Schiller University Jena, Lessingstrasse 8, D-07743 Jena, Germany
}

have the ability to impair phytoplankton proliferation and lyse algal cells in order to exploit the rich nutrient source (Meyer et al. 2017). Due to this potential they are discussed as causes for phytoplankton bloom collapse. For all pathogens including algicidal bacteria, a crucial factor for the ecological role in the environment is their host specificity that is often determined by phytoplankton resistance (Paul and Pohnert 2011). As a consequence of this specificity the lysis of a dominant susceptible phytoplankton species might open niches for resistant competitors, subsequently leading to a shift in phytoplankton composition. Such a shift has recently been shown in mesocosms after infection of a natural community with the algicidal bacterium Kordia algicida (Sohn) (Bigalke et al. 2019). The topic of specificity is also intensely studied in the fields of biotechnology and environmental engineering, especially in the control of harmful algal blooms (Gumbo et al. 2008, Seong and Jeong 2013, Shao et al. 2013). In these fields specificity is especially desirable since it allows the development of biocompatible tools that affect only the targeted species. In contrast to pathogenic bacteria, more is known about viruses that are highly abundant in marine systems as well (Brussaard and Martínez-Martínez 2008, Rohwer and Thurber 2009). One of the best-studied model systems is the coccolithophore Emiliania huxleyi (Lohmann) and its viruses (EhV) (Bidle and Vardi 2011, Rosenwasser et al. 2016). Infection of E. huxleyi with EhV even terminates blooms with large-scale ecological impact on plankton dynamics (Brussaard et al. 1996, Schroeder et al. 2002). However, both $E$. huxleyi and its viruses are heterogeneous populations in nature leading to survival of part of the E. huxleyi cells (Jacquet et al. 2002, Schroeder et al. 2002, 2003). This difference in susceptibility has been linked to the metabolic activity of individuals (Rosenwasser et al. 2016) as well as to dimethylsulfoniopropionate (DMSP)lyase activity (Schroeder et al. 2002). Also shifting from susceptible diploid to resistant haploid life form has been identified as an escape strategy in E. huxleyi (Frada et al. 2008). Other phytoplankton such as Phaeocystis pouchetii (Hariot) may escape viruses by colony formation (Jacobsen et al. 2007). Compared to viruses little is known about marine fungi that infect planktonic microalgae. In freshwater ecosystems chytrids have been intensely studied for 
their ability to modulate diatoms communities (Ibelings et al. 2004). Primarily, fungal effects on macroalgae are studied in marine environments (Gachon et al. 2010, Gleason et al. 2011, Richards et al. 2012). Reports on microalgae as fungal host are increasing (Sparrow 1969, Hanic et al. 2009, Garvette et al. 2018, Gladfelter et al. 2019) and also other parasitoids are studied (Tillmann et al. 1999, Peacock et al. 2014). However, reports on host range and resistance are scarce (Siano et al. 2011).

Most studies on the specificity of algicidal bacteria test only a very limited number of phytoplankton species and strains. Nevertheless, many generalize their findings to the species, genus or higher phylogenetic groups, potentially underestimating intra-species variability. Such variability has been shown on a genetic level but evidence for a functional diversity within a bloom is rather scarce (Medlin et al. 2000). We hypothesize here that resistance of algae and therewith specificity of bacteria can be species- and even strain dependent. In other fields of phycology many examples for intra-species variability have been found. This includes variability on the genetic level (Medlin et al. 1996, Bolch et al. 1999, Rynearson and Armbrust 2000), the concentration of secondary metabolites (Loret et al. 2002, Heil et al. 2005, Wichard et al. 2005, Taylor et al. 2009, Thessen et al. 2009, Rodriguez et al. 2017) as well as physiological and behavioral responses (Rynearson and Armbrust 2000, Laurion and Roy 2009, Fredrickson et al. 2011, Kremp et al. 2012, Harvey et al. 2015, Menden-Deuer and Montalbano 2015). However, only very few studies cover several strains of the same algal species when testing algicidal activity of bacteria (Mitsutani et al. 1992, Roth et al. 2008b, van Tol et al. 2016) making it difficult to systematically predict intra-specific variation in susceptibility. Furthermore, the studied strains are usually isolated from different locations at varying times. This difference in life history reduces comparability between the strains, especially when taking into account that the natural algal microbiome might influence resistance (Mayali and Doucette 2002, Roth et al. 2008a). This microbiome associated with the algae can vary depending on the time and place of isolation as has recently been shown in a comprehensive study (Ajani et al. 2018).

This study aims to systematically investigate the variability of susceptibility to the algicidal bacterium Kordia algicida within the genus Chaetoceros. The Flavobacterium $K$. algicida was isolated from a Skeletonema costatum (Greville) bloom at Masan Bay, Korea (Sohn et al. 2004). The Chaetoceros genus was chosen, since variability in susceptibility to $K$. algicida has already been observed with one resistant and one susceptible species identified (Paul and Pohnert 2011, Bigalke et al. 2019). The strains under study were isolated from one habitat and therefore share common life histories.

\section{Materials and methods}

\section{Isolation of Chaetoceros spp.}

Two water samples were taken from Scheldt Estuary (Netherlands) on 12th September 2015. Sample 1 was surface water from the quayside of the Havenkanaal (51.538791 N 3.927477 E). Sample 2 was surface water from the dyke (51.540310 N 3.929907 E). Samples were concentrated via a $10-\mu \mathrm{m}$ phytoplankton net and single cells or cell chains were subsequently isolated under a light microscope. Isolated cells grew into seven monoclonal cultures of Chaetoceros spp. (Table 1).

Chaetoceros socialis (Schutt) (accession number MH992142.1) was previously isolated from surface water at Helgoland Roads (Bigalke et al. 2019). Chaetoceros didymus (Cleve) (accession number MG914538.1) was isolated by W. Kooistra from the Mediterranean Sea (Stazione Zoologica Anton Dohrn, Naples, Italy). Both, C. socialis and $C$. didymus, are maintained in our culture collection.

\section{Diatom culturing and antibiotic treatment}

Diatoms were cultivated in artificial seawater medium (Maier and Calenberg 1994) at $50 \mu \mathrm{mol}$ photons $\mathrm{m}^{-2} \mathrm{~s}^{-1}$ in a $14 \mathrm{~h} / 10 \mathrm{~h}$ light and dark cycle. For antibiotic treatment $300 \mu \mathrm{g} \mathrm{ml}^{-1}$ penicillin $\mathrm{G}$ sodium salt, $2 \mu \mathrm{g} \mathrm{ml}^{-1}$ chloramphenicol, $2.4 \mu \mathrm{g} \mathrm{ml}^{-1}$ neomycin and $12 \mathrm{I} \cdot \mathrm{U} \cdot \mathrm{ml}^{-1}$ polymyxin B sulfate for $24 \mathrm{~h}$. Then $260 \mu \mathrm{g} \mathrm{ml}^{-1}$ cefotaxime sodium salt and $520 \mu \mathrm{g} \mathrm{ml}^{-1}$ carbenicillin disodium salt were added to the cultures and after $24-48 \mathrm{~h}$ cells were transferred to fresh culture medium.

\section{Genetic identification of Chaetoceros spp.}

Cells of Chaetoceros spp. were concentrated by centrifugation $\left(850 \mathrm{~g}, 4^{\circ} \mathrm{C}\right.$ for $\left.20 \mathrm{~min}\right)$, cell pellets were frozen $\left(-80^{\circ} \mathrm{C}\right)$ and freeze-dried. Dried cell pellets were lysed with zirconium beads $(0.9 \mathrm{~mm})$ for $1 \mathrm{~min}$ at $30 \mathrm{~Hz}$ in a TissueLyser II (Qiagen, Venlo, Netherlands) precooled to $-80^{\circ} \mathrm{C}$. Genomic DNA was isolated using the Isolate II Plant DNA Kit (Bioline GmbH, Berlin-Brandenburg, Germany) with lysis buffer PA1 without RNase. D1-D3 LSU rDNA was amplified based on an established protocol (Lundholm et al. 2002). The following primers were used: D1R-F [ACC CGC TGA ATT TAA GCA TA; (Nunn et al. 1996)], D3B-R [TCG GAG GGA ACC AGC TAC TA; (Lundholm et al. 2002)] and D3Ca [ACG AAC GAT TTG CAC GTC AG; 
(Scholin et al. 1994)] obtained from biomers.net GmbH (Ulm, Germany). The PCR mix contained OneTaq standard reaction buffer, $200 \mu \mathrm{M}$ dNTPs, forward and reverse primer (see Table 2), tetramethylammonium chloride or tetramethylammonium oxalate as additive (see Table 2) and 1.25 U OneTaq ${ }^{\circledR}$ DNA Polymerase (New England Biolabs, Frankfurt, Germany). The temperature program was: initial denaturation at $94^{\circ} \mathrm{C}$ for $2 \mathrm{~min}$; 30 cycles of denaturation $\left(94^{\circ} \mathrm{C}, 30 \mathrm{~s}\right)$, annealing (for temperature see Table 2, $30 \mathrm{~s})$ and elongation $\left(68^{\circ} \mathrm{C}, 60 \mathrm{~s}\right)$; final elongation at $68^{\circ} \mathrm{C}$ for $5 \mathrm{~min}$. The PCR product was purified from an HDGreen-stained (Intas Science Imaging Instruments $\mathrm{GmbH}$, Göttingen, Germany) 1\% agarose gel using the GenElute $^{\mathrm{TM}}$ Gel Extraction kit (Sigma-Aldrich, Munich, Germany) according to the manufacturer's instructions. Sanger sequencing was performed by GATC Biotech AG (Konstanz, Germany) using the same primers as for PCR. Sequences were aligned with selected sequences retrieved from GenBank using Clustal W (Thompson et al. 1994). The alignment was manually cropped in BioEdit (Hall 1999) to 731 nucleotides and used for maximum likelihood analysis in MEGA vers. 7.0.21 (Kumar et al. 2016). TamuraNei with discrete Gamma distribution (five categories; $+G$ parameter $=0.3501$ ) was determined as the best model (Tamura and Nei 1993). Nearest-Neighbor-Interchange was used as the heuristic method for tree inference. A log likelihood value of -2850.0182 was achieved by the most suitable tree after 1000 bootstraps.

\section{Algicidal bioassay}

Susceptibility of Chaetoceros spp. to the lytic activity of Kordia algicida OT-1 was tested via algal-bacterial coincubation. Therefore, $K$. algicida was cultured on marine broth agar plates for up to 2 days before being carefully

Table 1: Sampling information on newly isolated strains of Chaetoceros spp.

\begin{tabular}{lll}
\hline Accession number & Sampling & \\
\cline { 2 - 3 } & Location & Source \\
\hline MK421350 & $\begin{array}{l}\text { At the dyke } \\
51.540310 \mathrm{~N} 3.929907 \mathrm{E}\end{array}$ & Surface water; phytoplankton net $10 \mu \mathrm{m}$ \\
MK421351 & $\begin{array}{l}\text { At the dyke } \\
51.540310 \mathrm{~N} 3.929907 \mathrm{E}\end{array}$ & Surface water; phytoplankton net $10 \mu \mathrm{m}$ \\
MK421352 & $\begin{array}{l}\text { At the dyke } \\
51.540310 \mathrm{~N} 3.929907 \mathrm{E}\end{array}$ & Surface water; phytoplankton net $10 \mu \mathrm{m}$ \\
MK421353 & $\begin{array}{l}\text { Quayside of the Havenkanaal } \\
51.538791 \mathrm{~N} 3.927477 \mathrm{E}\end{array}$ & Surface water; scooping \\
MK421354 & $\begin{array}{l}\text { Quayside of the Havenkanaal } \\
51.538791 \mathrm{~N} 3.927477 \mathrm{E}\end{array}$ & Surface water; scooping \\
MK421355 & $\begin{array}{l}\text { Quayside of the Havenkanaal } \\
51.538791 \mathrm{~N} 3.927477 \mathrm{E}\end{array}$ & Surface water; scooping \\
MK421356 & Quayside of the Havenkanaal & Surface water; scooping \\
& $51.538791 \mathrm{~N} 3.927477 \mathrm{E}$ & \\
\hline
\end{tabular}

All strains were isolated on 12th September 2015.

Table 2: PCR parameters.

\begin{tabular}{|c|c|c|c|c|}
\hline Accession number & MK421350 & MK421351 & MK421352 & MK421353 \\
\hline fv Primer & $200 \mathrm{~nm}$ D1R-F & $1 \mu \mathrm{M}$ D1R-F & 200 nм D1R-F & $1 \mu \mathrm{M}$ D1R-F \\
\hline rv Primer & $200 \mathrm{~nm} \mathrm{D3Ca}$ & $1 \mu \mathrm{M}$ D3B-R & 200 nм D3Ca & $1 \mu \mathrm{M}$ D3B-R \\
\hline Additive & - & $1 \mathrm{~mm}$ TMA oxalate & - & $20 \mathrm{~mm}$ TMA Cl \\
\hline \multirow{2}{*}{$T_{\text {annealing }}$} & $49^{\circ} \mathrm{C}$ & $60^{\circ} \mathrm{C}$ & $49^{\circ} \mathrm{C}$ & $60^{\circ} \mathrm{C}$ \\
\hline & MK421354 & MK421355 & MK421356 & \\
\hline fv Primer & $1 \mu \mathrm{M}$ D1R-F & $1 \mu \mathrm{M}$ D1R-F & $1 \mu \mathrm{M}$ D1R-F & \\
\hline rv Primer & $1 \mu \mathrm{M}$ D3B-R & $1 \mu \mathrm{M}$ D3B-R & $1 \mu \mathrm{M}$ D3B-R & \\
\hline Additive & $1 \mathrm{~mm}$ TMA oxalate & $1 \mathrm{~mm}$ TMA oxalate & $20 \mathrm{~mm}$ TMA Cl & \\
\hline $\mathrm{T}_{\text {annealing }}$ & $60^{\circ} \mathrm{C}$ & $60^{\circ} \mathrm{C}$ & $60^{\circ} \mathrm{C}$ & \\
\hline
\end{tabular}

The forward and reverse primer with the used concentration are given as well as the additive and annealing temperature. 
removed with a cotton swab and resuspended in artificial seawater medium. Triplicates of exponentially growing algal cultures $(40 \mathrm{ml}$ ) were infected with this $K$. algicida suspension to a bacterial optical density of $\mathrm{OD}_{550} 0.01$. An equal volume of medium without bacteria was added to control cultures in triplicates. Algal growth was monitored by in vivo chlorophyll $a$ fluorescence for 9-10 days using a Mithras LB 940 plate reader (Berthold Technologies, Bad Wildbad, Germany). The diatom Skeletonema costatum was used as a positive control to test for algicidal activity of the bacteria used.

\section{Results}

Monoclonal cultures were isolated from two water samples taken from the Scheldt Estuary (Netherlands). Cultures tentatively identified as Chaetoceros spp. by light microscopy were further purified by serial transfer and antibiotic treatments. Analysis of $28 \mathrm{~S}$ rDNA confirmed the morphological identification and provided the basis to include the strains in the Chaetoceros phylogeny (Li et al. 2015). The newly isolated strains cluster with Chaetoceros elegans, Chaetoceros curvisetus, Chaetoceros pseudocurvisetus and Chaetoceros protuberans (Figure 1).

All seven newly isolated strains were subjected to bioassays to test for resistance against the algicidal bacterium Kordia algicida (Figure 1). Additionally, a strain of Chaetoceros didymus and of Chaetoceros socialis was included in the bioassays, as strains known to be resistant or susceptible from previous studies. The strains of $C$. elegans and $C$. socialis were susceptible to lysis by $K$. algicida (Figure $2 \mathrm{~F}, \mathrm{~J}$ ) while the strains of $C$. didymus and $C$. curvisetus were resistant (Figure 2B, I). For $C$. pseudo-curvisetus and $C$. protuberans multiple strains were isolated. One of three $C$. pseudo-curvisetus and one of two C. protuberans strains were resistant (Figure 2C, $\mathrm{H})$. Resistant isolates showed similar growth in control and bacteria-treated cultures, while susceptible isolates died completely if treated with bacteria before control cultures reached maximum density (Figure 2). Demise

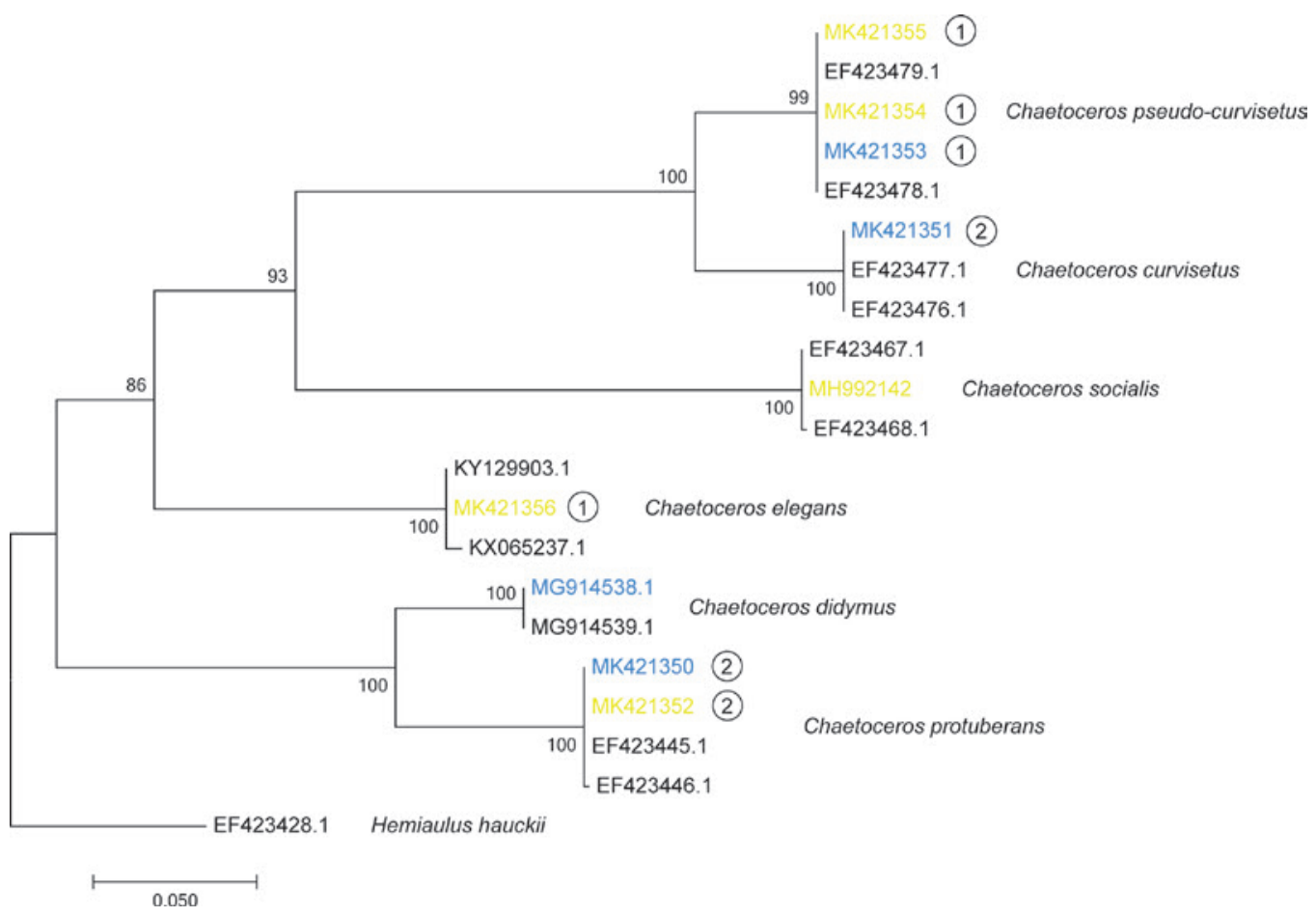

Figure 1: Phylogeny of Chaetoceros genus including isolated strains.

Strains resistant to Kordia algicida are marked in blue, strains susceptible in yellow. Newly isolated strains are marked with encircled numbers representing the sample from which the strain was isolated (1, quayside of the Havenkanaal; 2, at the dyke, concentrated via 10- $\mu \mathrm{m}$ phytoplankton net). Chaetoceros didymus and $C$. socialis were used as known resistant and susceptible strains, respectively. Reference sequences for phylogenetic inference from GenBank of strains not tested in bioassays are marked in black. Maximum likelihood analysis of LSU rDNA with 1000 bootstraps using Tamura-Nei model with 5 discrete gamma categories and nearest-neighbor-interchange. Branch length depicts the number of substitutions per site. 

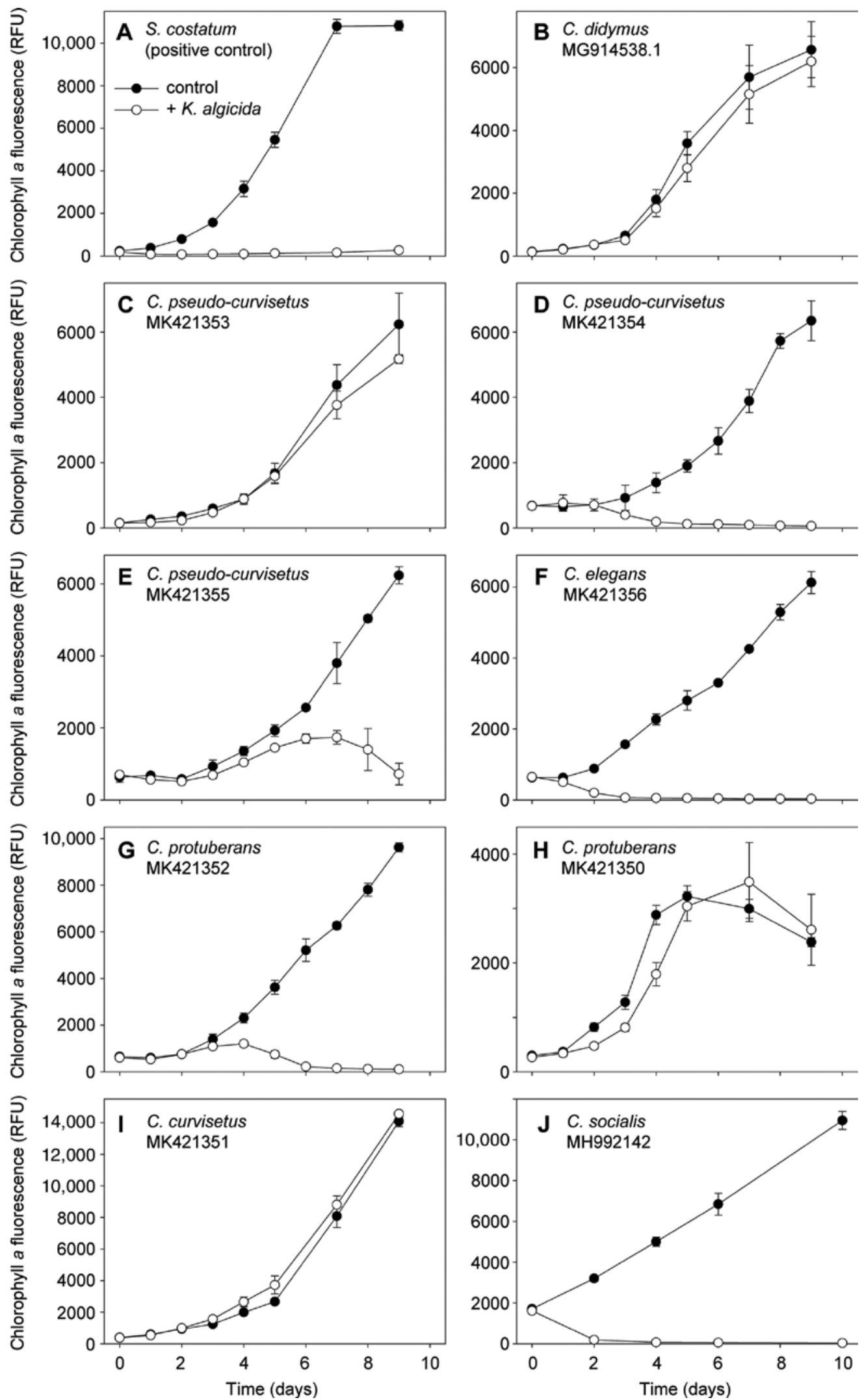

Figure 2: Growth of Chaetoceros strains in the absence and presence of Kordia algicida.

Growth was monitored by in-vivo chlorophyll a fluorescence (RFU, relative fluorescent units). Skeletonema costatum was used as a positive control for algicidal activity of $K$. algicida. 
of susceptible cultures differed in speed. Some isolates did not grow at all in the presence of the bacteria (e.g. C. pseudo-curvisetus MK421354, Figure 2D) while others showed initial growth for a few days before cultures collapsed (e.g. C. pseudo-curvisetus MK421355, Figure 2E).

\section{Discussion}

The results presented here show that susceptibility of a diatom to an algicidal bacterium can vary between species of the same genus and even between isolates of a single species obtained at one time within one habitat. The reason for the heterogeneity in susceptibility of Chaetoceros spp. to K. algicida is unknown. Since proteases and oxylipins are potentially involved in the resistance of Chaetoceros didymus (Paul and Pohnert 2013, Meyer et al. 2018) strain-specific differences on the level of enzymes or secondary metabolites may play a role for the plasticity of susceptibility and should be investigated further. This hypothesis is in agreement with studies from other algae that report intra-species variability in the level of secondary metabolites (Loret et al. 2002, Heil et al. 2005, Wichard et al. 2005, Taylor et al. 2009, Thessen et al. 2009, Rodriguez et al. 2017).

Broadening the view to other phytoplankton pathogens, the results obtained here for interaction with bacteria are in agreement with observations on algal viruses. In mesocosm experiments, individual cells of Emiliania huxleyi survived bloom termination by viruses (Jacquet et al. 2002). For E. huxleyi variance in resistance and susceptibility could be correlated to DMSP-lyse activity (Schroeder et al. 2002). Strains with high enzyme activity, which enables breakdown of DMSP to dimethyl sulfide (DMS) and acrylate, were resistant to viral infection. Other anti-viral strategies that have been reported, like E. huxleyi changing from a susceptible diploid to a resistant haploid life form (Frada et al. 2008) or colony formation in Phaeocystis pouchetii (Jacobsen et al. 2007) are not possible due to the life cycle of Chaetoceros (French and Hargraves 1985). However, diatoms have the ability to form resting stages (McQuoid and Hobson 1996) that could potentially confer resistance.

Despite all these indications, susceptibility to algicidal bacteria is generally considered a common trait of a species or higher phylogenetic group but our work calls for revision of this view. Variability of resistance against bacteria has already been observed for other diatoms as well, thus, for example, in two strains of Pseudo-nitzschia multiseries from different sources, the growth inhibition by Croceibacter atlanticus differed greatly (van Tol et al. 2016). For Phaeodactylum tricornutum two morphotypes with different antibacterial activity have been identified (Desbois et al. 2010). Also among dinoflagellates from the Karenia and Alexandrium genus, strain-specific resistance to algicidal bacteria has been described, but resistance was attributed to the associated microbial community (Mayali and Doucette 2002, Roth et al. 2008b). Our study now demonstrates specificity even within one population in the field and sheds light on the individuality of cells even within a mono species plankton population.

Antibiotic treatment during algal isolation partly removed the natural microbiome. However, cultures used for our experiments were likely xenic due to survival of closely associated bacteria. Bacteria within the phycosphere may be additional interaction partners and may modulate algicidal activity (Mayali and Doucette 2002, Roth et al. 2008a, Seymour et al. 2017). The associated microbiome can differ depending on the time and place of algal isolation (Ajani et al. 2018). To minimize this effect, algal isolates from the same natural population were studied here.

In conclusion, the heterogeneity in plankton communities documented here shown as an example for the Chaetoceros genus should be taken into account when discussing the ecological role of algicidal bacteria. Especially when their use in ecosystem engineering is considered, the complexity and heterogeneity of the plankton should not be oversimplified. Survival of a few resistant cells within a bloom could even select for resistance traits.

Acknowledgments: The authors acknowledge all trainers and participants of the course "Algal Biodiversity" at Ghent University in 2015, especially Pieter Vanormelingen, for support in diatom isolation. Wiebe Kooistra is acknowledged for providing the Chaetoceros didymus strain. The authors acknowledge financial support from the German Research Foundation (Funder Id: http:// dx.doi.org/10.13039/501100001659) within the framework of the CRC 1127 ChemBioSys.

\section{References}

Ajani, P.A., T. Kahlke, N. Siboni, R. Carney, S.A. Murray and J.R. Seymour. 2018. The microbiome of the cosmopolitan diatom Leptocylindrus reveals significant spatial and temporal variability. Front. Microbiol. 9: 2758.

Amin, S.A., M.S. Parker and E.V. Armbrust. 2012. Interactions between diatoms and bacteria. Microbiol. Mol. Biol. Rev. 76: 667-684. 
Behrenfeld, M.J., R.T. O’Malley, D.A. Siegel, C.R. McClain, J.L. Sarmiento, G.C. Feldman, A.J. Milligan, P.G. Falkowski, R.M. Letelier and E.S. Boss. 2006. Climate-driven trends in contemporary ocean productivity. Nature 444: 752-755.

Bidle, K.D. and A. Vardi. 2011. A chemical arms race at sea mediates algal host-virus interactions. Curr. Opin. Microbiol. 14: 449-457.

Bigalke, A., N. Meyer, L. Papanikolopoulou, K.H. Wiltshire and G. Pohnert. 2019. The algicidal bacterium Kordia algicida shapes a natural plankton community. Appl. Environ. Microb. 85: e02779-18.

Bolch, C.J.S., S.I. Blackburn, G.M. Hallegraeff and R.E. Vaillancourt. 1999. Genetic variation among strains of the toxic dinoflagellate Gymnodinium catenatum (Dinophyceae). J. Phycol. 35: 356-367.

Brussaard, C.P.D. and J. Martínez-Martínez. 2008. Algal bloom viruses. Plant Viruses 2: 1-13.

Brussaard, C.P.D., R.S. Kempers, A.J. Kop, R. Riegman and M. Heldal. 1996. Virus-like particles in a summer bloom of Emiliania huxleyi in the North Sea. Aquat. Microb. Ecol. 10: 105-113.

Desbois, A.P., M. Walton and V.J. Smith. 2010. Differential antibacterial activities of fusiform and oval morphotypes of Phaeodactylum tricornutum (Bacillariophyceae). J. Mar. Biol. Assoc. UK 90: 769-774.

Frada, M., I. Probert, M.J. Allen, W.H. Wilson and C. de Vargas. 2008. The "Cheshire Cat" escape strategy of the coccolithophore Emiliania huxleyi in response to viral infection. Proc. Natl. Acad. Sci. U.S.A. 105: 15944-15949.

Fredrickson, K.A., S.L. Strom, R. Crim and K.J. Coyne. 2011. Interstrain variability in physiology and genetics of Heterosigma Akashiwo (Raphidophyceae) from the west coast of North America. J. Phycol. 47: 25-35.

French, F.W. and P.E. Hargraves. 1985. Spore formation in the life cycles of the diatoms Chaetoceros diadema and Leptocylindrus danicus. J. Phycol. 31: 477-483.

Gachon, C.M.M., T. Sime-Ngando, M. Strittmatter, A. Chambouvet and G.H. Kim. 2010. Algal diseases: spotlight on a black box. Trends Plant Sci. 15: 633-640.

Garvette, A., E. Nezan, Y. Badis, G. Bilien, P. Arce, E. Bresnan, C.M.M. Gachon and R. Siano. 2018. Novel widespread marine oomycetes parasitising diatoms, including the toxic genus Pseudo-nitzschia: genetic, morphological, and ecological characterisation. Front. Microbiol. 9: 2918.

Gladfelter, A.S., T.Y. James and A.S. Amend. 2019. Marine fungi. Curr. Biol. 29: R191-R195.

Gleason, F.H., F.C. Kuepper, J.P. Amon, K. Picard, C.M.M. Gachon, A.V. Marano, T. Sime-Ngando and O. Lilje. 2011. Zoosporic true fungi in marine ecosystems: a review. Mar. Freshwater Res. 62: 383-393.

Gumbo, R.J., G. Ross and E.T. Cloete. 2008. Biological control of Microcystis dominated harmful algal blooms. Afr. J. Biotechnol. 7: 4765-4773.

Hall, T.A. 1999. BioEdit: a user-friendly biological sequence alignment editor and analysis program for Windows 95/98/NT. Nucl. Acids Symp. Ser. 41: 95-98.

Hanic, L.A., S. Sekimoto and S.S. Bates. 2009. Oomycete and chytrid infections of the marine diatom Pseudo-nitzschia pungens (Bacillariophyceae) from Prince Edward Island, Canada. Botany 87: 1096-1105.

Harvey, E.L., S. Menden-Deuer and T.A. Rynearson. 2015. Persistent intra-specific variation in genetic and behavioral traits in the Raphidophyte Heterosigma akashiwo. Front. Microbiol. 6: 1277.
Heil, C.A., P.M. Glibert and C.L. Fan. 2005. Prorocentrum minimum (Pavillard) Schiller - a review of a harmful algal bloom species of growing worldwide importance. Harmful Algae 4: 449-470.

Ibelings, B.W., A. De Bruin, M. Kagami, M. Rijkeboer, M. Brehm and E. van Donk. 2004. Host parasite interactions between freshwater phytoplankton and chytrid fungi (Chytridiomycota). J. Phycol. 40: 437-453.

Jacobsen, A., A. Larsen, J. Martinez-Martinez, P.G. Verity and M.E. Frischer. 2007. Susceptibility of colonies and colonial cells of Phaeocystis pouchetii (Haptophyta) to viral infection. Aquat. Microb. Ecol. 48: 105-112.

Jacquet, S., M. Heldal, D. Iglesias-Rodriguez, A. Larsen, W. Wilson and G. Bratbak. 2002. Flow cytometric analysis of an Emiliana huxleyi bloom terminated by viral infection. Aquat. Microb. Ecol. 27: 111-124.

Kremp, A., A. Godhe, J. Egardt, S. Dupont, S. Suikkanen, S. Casabianca and A. Penna. 2012. Intraspecific variability in the response of bloom-forming marine microalgae to changed climate conditions. Ecol. Evol. 2: 1195-1207.

Kumar, S., G. Stecher and K. Tamura. 2016. MEGA7: molecular evolutionary genetics analysis version 7.0 for bigger datasets. Mol. Biol. Evol. 33: 1870-1874.

Laurion, I. and S. Roy. 2009. Growth and photoprotection in three Dinoflagellates (including two strains of Alexandrium tamarense) and one diatom exposed to four weeks of natural and enhanced ultraviolet-B radiation. J. Phycol. 45: 16-33.

Li, Y., S.Y. Zhu, N. Lundholm and S.H. Lu. 2015. Morphology and molecular phylogeny of Chaetoceros dayaensis sp. nov. (Bacillariophyceae), characterized by two 90 degrees rotations of the resting spore during maturation. J. Phycol. 51: 469-479.

Loret, P., T. Tengs, T.A. Villareal, H. Singler, B. Richardson, P. McGuire, S. Morton, M. Busman and L. Campbell. 2002. No difference found in ribosomal DNA sequences from physiologically diverse clones of Karenia brevis (Dinophyceae) from the Gulf of Mexico. J. Plankton Res. 24: 735-739.

Lundholm, N., N. Daugbjerg and O. Moestrup. 2002. Phylogeny of the Bacillariaceae with emphasis on the genus Pseudonitzschia (Bacillariophyceae) based on partial LSU rDNA. Eur. J. Phycol. 37: 115-134.

Maier, I. and M. Calenberg. 1994. Effect of extracellular Ca2 + and $\mathrm{Ca} 2+$-antagonists on the movement and chemoorientation of male gametes of Ectocarpus siliculosus (Phaeophyceae). Bot. Acta 107: 451-460.

Mayali, X. and G.J. Doucette. 2002. Microbial community interactions and population dynamics of an algicidal bacterium active against Karenia brevis (Dinophyceae). Harmful Algae 1: 277-293.

McQuoid, M.R. and L.A. Hobson. 1996. Diatom resting stages. J. Phycol. 32: 889-902.

Medlin, L.K., G.L.A. Barker, L. Campbell, J.C. Green, P.K. Hayes, D. Marie, S. Wrieden and D. Vaulot. 1996. Genetic characterisation of Emiliania huxleyi (Haptophyta). J. Marine Syst. 9: 13-31.

Medlin, L.K., M. Lange and E.M. Nothig. 2000. Genetic diversity in the marine phytoplankton: a review and a consideration of Antarctic phytoplankton. Antarct. Sci. 12: 325-333.

Menden-Deuer, S. and A.L. Montalbano. 2015. Bloom formation potential in the harmful dinoflagellate Akashiwo sanguinea: clues from movement behaviors and growth characteristics. Harmful Algae 47: 75-85. 
Meyer, N., A. Bigalke, A. Kaulfuss and G. Pohnert. 2017. Strategies and ecological roles of algicidal bacteria. Fems Microbiol. Rev. 41: 880-899.

Meyer, N., J. Rettner, M. Werner, O. Werz and G. Pohnert. 2018. Algal oxylipins mediate the resistance of diatoms against algicidal bacteria. Mar. Drugs 16. doi: 10.3390/md16120486.

Mitsutani, A., K. Takesue, M. Kirita and Y. Ishida. 1992. Lysis of Skeletonema costatum by Cytophaga sp. isolated from the coastal water of the Ariake Sea. Nippon Suisan Gakk. 58: 2159-2167.

Nunn, G.B., B.F. Theisen, B. Christensen and P. Arctander. 1996. Simplicity-correlated size growth of the nuclear $28 \mathrm{~S}$ ribosomal RNA D3 expansion segment in the crustacean order Isopoda. J. Mol. Evol. 42: 211-223.

Paul, C. and G. Pohnert. 2011. Interactions of the algicidal bacterium Kordia algicida with diatoms: regulated protease excretion for specific algal lysis. PLoS One 6: e21032.

Paul, C. and G. Pohnert. 2013. Induction of protease release of the resistant diatom Chaetoceros didymus in response to lytic enzymes from an algicidal bacterium. PLoS One 8: e57577.

Peacock, E.E., R.J. Olson and H.M. Sosik. 2014. Parasitic infection of the diatom Guinardia delicatula, a recurrent and ecologically important phenomenon on the New England Shelf. Mar. Ecol. Prog. Ser. 503: 1-10.

Richards, T.A., M.D.M. Jones, G. Leonard and D. Bass. 2012. Marine fungi: their ecology and molecular diversity. Annu. Rev. Mar. Sci. 4: 495-522.

Rodriguez, I., A. Alfonso, E. Alonso, J.A. Rubiolo, M. Roel, A. Vlamis, P. Katikou, S.A. Jackson, M.L. Menon, A. Dobson and L.M. Botana. 2017. The association of bacterial C-9-based TTX-like compounds with Prorocentrum minimum opens new uncertainties about shellfish seafood safety. Sci. Rep. 7: 40880.

Rohwer, F. and R.V. Thurber. 2009. Viruses manipulate the marine environment. Nature 459: 207-212.

Rosenwasser, S., C. Ziv, S.G. Van Creveld and A. Vardi. 2016. Virocell metabolism: metabolic innovations during host-virus interactions in the Ocean. Trends Microbiol. 24: 821-832.

Roth, P.B., C.M. Mikulskil and G.J. Doucette. 2008a. Influence of microbial interactions on the susceptibility of Karenia spp. to algicidal bacteria. Aquat. Microb. Ecol. 50: 251-259.

Roth, P.B., M.J. Twiner, C.M. Mikulski, A.B. Barnhorst and G.J. Doucette. 2008b. Comparative analysis of two algicidal bacteria active against the red tide dinoflagellate Karenia brevis. Harmful Algae 7: 682-691.

Rynearson, T.A. and E.V. Armbrust. 2000. DNA fingerprinting reveals extensive genetic diversity in a field population of the centric diatom Ditylum brightwellii. Limnol. Oceanogr. 45: 1329-1340.

Scholin, C.A., M.C. Villac, K.R. Buck, J.M. Krupp, D.A. Powers, G.A. Fryxell and F.P. Chavez. 1994. Ribosomal DNA sequences discriminate among toxic and non-toxic Pseudonitzschia species. Nat. Toxins 2: 152-165.

Schroeder, D.C., J. Oke, G. Malin and W.H. Wilson. 2002. Coccolithovirus (Phycodnaviridae): Characterisation of a new large dsDNA algal virus that infects Emiliana huxleyi. Arch. Virol. 147: 1685-1698.

Schroeder, D.C., J. Oke, M. Hall, G. Malin and W.H. Wilson. 2003. Virus succession observed during an Emiliania huxleyi bloom. Appl. Environ. Microb. 69: 2484-2490.

Seong, K.A. and H.J. Jeong. 2013. Interactions between marine bacteria and red tide organisms in Korean waters. Algae-Seoul 28: 297-305.
Seymour, J.R., S.A. Amin, J.B. Raina and R. Stocker. 2017. Zooming in on the phycosphere: the ecological interface for phytoplankton-bacteria relationships. Nat. Microbiol. 2: 17065.

Shao, J.H., R.H. Li, J.E. Lepo and J.D. Gu. 2013. Potential for control of harmful cyanobacterial blooms using biologically derived substances: problems and prospects. J. Environ. Manage. 125: 149-155.

Siano, R., C. Alves-de-Souza, E. Foulon, E.M. Bendif, N. Simon, L. Guillou and F. Not. 2011. Distribution and host diversity of Amoebophryidae parasites across oligotrophic waters of the Mediterranean Sea. Biogeosciences 8: 267-278.

Sohn, J.H., J.H. Lee, H. Yi, J. Chun, K.S. Bae, T.Y. Ahn and S.J. Kim. 2004. Kordia algicida gen. nov., sp nov., an algicidal bacterium isolated from red tide. Int. J. Syst. Evol. Micr. 54: 675-680.

Sparrow, F.K. 1969. Zoosporic marine fungi from the Pacific Northwest (U.S.A.). Arch. Mikrobiol. 66: 129-146.

Tamura, K. and M. Nei. 1993. Estimation of the number of nucleotide substitutions in the control region of mitochondrial-DNA in humans and chimpanzees. Mol. Biol. Evol. 10: 512-526.

Taylor, R.L., K. Abrahamsson, A. Godhe and S.A. Wangberg. 2009. Seasonal variability in polyunsaturated aldehyde production potential among strains of Skeletonema marinoi (Bacillariophyceae). J. Phycol. 45: 46-53.

Thessen, A.E., H.A. Bowers and D.K. Stoecker. 2009. Intra- and interspecies differences in growth and toxicity of Pseudonitzschia while using different nitrogen sources. Harmful Algae 8: 792-810.

Thompson, J.D., D.G. Higgins and T.J. Gibson. 1994. CLUSTAL W: improving the sensitivity of progressive multiple sequence alignment through sequence weighting, position-specific gap penalties and weight matrix choice. Nucleic Acids Res. 22: 4673-4680.

Tillmann, U., K.J. Hesse and A. Tillmann. 1999. Large-scale parasitic infection of diatoms in the Northfrisian Wadden Sea. J. Sea Res. 42: 255-261.

van Tol, H.M., S.A. Amin and E.V. Armbrust. 2016. Ubiquitous marine bacterium inhibits diatom cell division. ISME J. 11: 31-42.

Wichard, T., S.A. Poulet, C. Halsband-Lenk, A. Albaina, R. Harris, D. Liu and G. Pohnert. 2005. Survey of the chemical defence potential of diatoms: Screening of fifty one species for $\alpha, \beta, \gamma, \delta$ unsaturated aldehydes. J. Chem. Ecol. 31: 949-958.

\section{Bionotes}

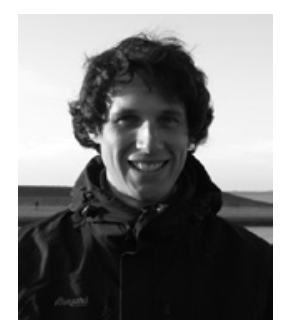

\section{Nils Meyer}

Institute for Inorganic and Analytical Chemistry, Bioorganic Analytics, Friedrich Schiller University Jena, Lessingstrasse 8, D-07743 Jena, Germany

Nils Meyer is a PhD researcher at the Institute for Inorganic and Analytical Chemistry, Friedrich Schiller University Jena. After obtaining a Master's degree in Chemical Biology (University Jena) he joined the collaborative research center ChemBioSys to study the chemical interaction of phytoplankton and algicidal bacteria. 


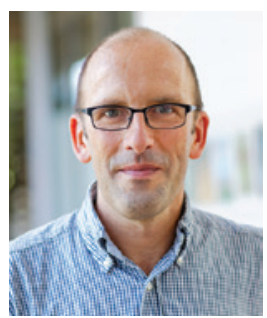

\section{Georg Pohnert}

Institute for Inorganic and Analytical Chemistry, Bioorganic Analytics, Friedrich Schiller University Jena, Lessingstrasse 8, D-07743 Jena, Germany; and Max Planck Institute for Chemical Ecology, Hans Knöll Str. 8, D-07745 Jena, Germany georg.pohnert@uni-jena.de

In his PhD at the University of Bonn Georg Pohnert investigated the biosynthesis and function of algal pheromones. He then moved to Cornell University where he did a postdoc in biophysics. His independent research career started at the Max Planck Institute for Chemical Ecology where he focused on chemical interactions of micro- and macroalgae - a topic that is also his current research focus at the Friedrich Schiller University Jena where he holds a chair in Bioorganic Analytics. 